\title{
PERTANGGUNGJAWABAN PIDANA BAGI ANAK YANG MELAKUKAN KEKERASAN FISIK TERHADAP PEMBANTU RUMAH TANGGA
}

(Analisis Putusan Nomor: 27/Pid.Sus-Anak/2014/PN.MDN)

Atikah Rahmi dan Suci Putri Lubis

\author{
Fakultas Hukum Universitas Muhammadiyah Sumatera Utara \\ E-mail: atikahrahmi@umsu.ac.id
}

\begin{abstract}
The imposition of criminal sanctions on children effects bad mental for development of children. Medan District Court has given criminal sanctions to children through Decision Number: 27/Pid.Sus-Anak/2014/Pn.Mdn. This verdict becomes interesting object to examine in aiming to know the criminal liability imposed on the child by analyzing the decision. This research is a normative juridical research with case approach, while its characteristic is descriptive. Data analysis is done by qualitative juridical. Based on the results of the research and analysis carried out that criminal liability of court handed over the child is considered ineffective, because the modern punishment system does not apply torture to children but more attention to the best interests for children.
\end{abstract}

\section{Kata Kunci: KDRT, Kekerasan Fisik, Pertanggungjawaban Pidana}

\section{A. Latar Belakang}

Permasalahan pidana telah menyerap banyak energi para anak bangsa untuk membangun rekonstruksi sosial. Meningkatnya aktivitas kriminal dalam berbagai bentuk menuntut kerja keras dalam membangun pemikiran-pemikiran baru mengenai arah kebijakan hukum di masa depan. Arah kebijakan hukum bertujuan menjadikan hukum sebagai aturan yang memberikan perlindungan bagi hak-hak warga negara dan menjamin kehidupan generasi di masa depan. Oleh karena itu, sistem hukum tiap negara dalam praktiknya terus mengalami modernisasi dan tidak ada satu negara pun yang dapat menolaknya. Contohnya negara Indonesia yang menuntut dilakukannya perubahan di segala bidang, di antaranya perubahan bidang hukum dengan memunculkan pemikiran-pemikiran baru untuk mereformasi hukum yang ada saat ini (Marlina, 2012: 2). Hal ini terlihat dengan dikeluarkannya kebijakan-kebijakan hukum dalam menangani 
kasus-kasus yang menyangkut tentang anak, baik anak sebagai korban maupun anak sebagai pelaku tindak pidana dengan dikeluarkannya Undang-undang Nomor 23 Tahun 2002 tentang Perlindungan Anak sebagaimana telah diubah dengan Undang-undang Nomor 35 Tahun 2014 tentang Perubahan Atas Undang-undang Republik Indonesia Nomor 23 Tahun 2002 tentang Perlindungan Anak dan berikut keluar pula Undang-undang Republik Indonesia Nomor 11 Tahun 2012 tentang Sistem Peradilan Anak.

Anak adalah generasi penerus bangsa yang memiliki keterbatasan dalam memahami dan melindungi diri dari berbagai pengaruh sistem yang ada. Masa anak-anak adalah masa yang sangat rawan melakukan tindakan, karena masa anak-anak suatu masa yang sangat rentan dengan berbagai keinginan dan harapan untuk mencapai sesuatu ataupun melakukan sesuatu (Aminah Aziz, 2000: 10), oleh karena itu, pemeliharaan kelangsungan hidup anak adalah tanggung jawab orang tua yang tidak boleh diabaikan.

Pasal 45 Undang-undang Nomor 1 Tahun 1974 tentang Pokok-pokok Perkawinan, menentukan bahwa orang tua wajib memelihara dan mendidik anak yang belum dewasa sampai anak-anak yang bersangkutan dewasa atau dapat berdiri sendiri. Berdasarkan Pasal 9 Undang-undang Nomor 4 Tahun 1979 tentang Kesejahteraan Anak, maka dapat pula diketahui bahwa orang tua merupakan pihak yang pertama-tama bertanggungjawab atas terwujudnya kesejahteraan anak baik secara rohani, jasmani maupun sosial (Maidin Gultom, 201: 1), tetapi dalam kenyataannya, banyak orang tua yang tidak menyadari hal ini, sehingga memberi dampak tidak baik yang mempengaruhi kehidupan anak. Anak yang dibesarkan dalam suasana konflik, cenderung mengalami keresahan jiwa, yang dapat mendorong anak melakukan tindakan-tindakan yang negatif, yang dikategorikan sebagai kenakalan anak (Maidin Gultom, 2011: 2).

Kenakalan anak sering disebut dengan juvenile deliquency, yang diartikan dengan anak cacat sosial. Deliquency adalah suatu tindakan atau perbuatan yang dilakukan oleh seorang anak yang dianggap bertentangan dengan ketentuanketentuan hukum yang berlaku di suatu negara dan yang oleh masyarakat itu sendiri dirasakan serta ditafsirkan sebagai perbuatan yang tercela (Maidin Gultom, 
201: 67). Anak sebagai anggota masyarakat hendaknya harus menjunjung tinggi norma-norma yang hidup di dalam masyarakat, apabila dia melanggar norma tersebut, maka dia harus mempertanggungjawabkan perbuatannya.

Pemberian pertanggungjawaban pidana terhadap anak harus mempertimbangkan perkembangan dan kepentingan terbaik anak di masa yang akan datang. Penanganan yang salah menyebabkan rusak bahkan musnahnya bangsa di masa depan, karena anak adalah generasi penerus bangsa dan cita-cita negara, dan ketika anak menjadi pelaku tindak pidana, negara harus memberikan perlindungan kepada anak melalui berbagai peraturan perundang-undangan yang tersebut di atas. Pelaksanaan sistem peradilan pidana di Indonesia masih menghadapi berbagai persoalan, antara lain dilakukannya penahanan terhadap anak, proses peradilan yang panjang mulai dari penyidikan, penuntutan, pengadilan, yang pada akhirnya menempatkan terpidana anak berada dalam lembaga pemasyarakatan yang meninggalkan trauma dan implikasi negatif terhadap anak, padahal anak perlu mendapat perlindungan kesalahan dari penerapan peraturan perundangundangan yang diberlakukan terhadap dirinya, yang dapat menimbulkan kerugian mental, fisik, dan sosial.

Kondisi yang paling memungkinkan guna pencapaian hasil yang optimal atas cita-cita tersebut adalah terciptanya kondisi sosial yang kondusif, dan merupakan tanggung jawab negara dalam menciptakan kondisi yang semacam itu. Kondisi sosial yang kondusif selalu ditandai dengan perkembangan perekonomian yang merata di seluruh masyarakat yang ada, dan hal itu sudah barang tentu harus didukung oleh sebuah sistem hukum yang baik dalam mengawali pembangunan ekonomi yang baik, karena menurut Tengku Erwinsyahbana (2012: 81) dikatakan bahwa: substansi hukum yang baik merupakan syarat mutlak yang harus dipenuhi untuk mewujudkan tujuan hukum, yaitu: (1) kepastian hukum; (2) kemanfaatan hukum; dan (3) keadilan hukum.

Realitas sosial menunjukkan bahwa kondisi kondusif tersebut belum dapat diwujudkan oleh pemerintah, di tengah globalisasi yang terus melaju, negara ini nampaknya mengalami anomie kondisi di mana sosial kehilangan nilai dan patokan-patokan hidup. Pemenuhan ekonomi yang menjadi barometer kesuksesan 
hidup menyebabkan banyaknya penyimpangan-penyimpangan yang dilakukan oleh masyarakat dalam mencapainya, tidak terkecuali juga dilakukan oleh anak yang merupakan generasi muda bangsa ini. Akibat keadaan seperti ini maka, penanganan anak harus menjadi perhatian yang serius, dengan demikian penanganan secara hukum terhadap anak harus pula memerhatikan sifat-sifat khas anak.

Sebenarnya terlalu ekstrim apabila tindak pidana yang dilakukan oleh anak-anak disebut dengan kejahatan, karena pada dasarnya anak-anak memiliki kondisi kejiwaan yang labil, proses kemantapan psikis menghasilkan sikap kritis, agresif dan menunjukkan tingkah laku yang cenderung bertindak mengganggu ketertiban umum. Hal ini belum dapat dikatakan sebagai kejahatan, melainkan kenakalan yang ditimbulkan akibat dari kondisi psikologis yang tidak seimbang dan si pelaku belum sadar dan mengerti atas tindakan yang telah dilakukan anak (M. Nasir Djamil, 2012: 33-34).

Sebagai contoh kasus yang dapat diambil adalah tindak pidana kekerasan dalam lingkup rumah tangga dan bersama-sama menyembunyikan mayat yang dilakukan oleh anak di bawah umur pada tahun 2014 di Medan. Pengadilan Negeri Medan menjatuhkan putusan pidana penjara selama 1 (satu) tahun 8 (delapan) bulan di Lembaga Pembinaan Khusus Anak (yang selanjutnya disingkat dengan LPKA) Medan terhadap terdakwa Muhammad Tariq Anwar alias Pai yang secara sah dan meyakinkan melakukan tindak pidana sebagaimana yang dituduhkan kepadanya sesuai Putusan Nomor: 27/Pid.Sus-Anak/2014/PN.MDN. Adapun penjatuhan hukuman pidana penjara tehadap anak di bawah umur ini didasari oleh Undang-undang Republik Indonesia Nomor 23 Tahun 2004 tentang Penghapusan Kekerasan Dalam Rumah Tangga.

Anak yang berkedudukan sebagai pelaku dalam kasus ini juga sekaligus korban dari pola didik orang tua, karena anak dibesarkan dalam keluarga yang yang sering melakukan kekerasan fisik terhadap para pembantunya, sehingga jelas mendidik kepada anak bahwa kekerasan fisik terhadap orang lain merupakan hal yang biasa bagi keluarga mereka. Pola didikan seperti inilah yang menjadikan anak berkepribadian keras, sehingga anak tanpa ada rasa iba melakukan kekerasan 
fisik kepada para pembantu rumah tangganya yang berujung pidana. Kasus ini menarik untuk diteliti yang bertujuan untuk mengetahui pertanggungjawaban pidana terhadap anak yang melakukan kekerasan fisik dalam rumah tangga berdasarkan putusan Nomor: 27/Pid.Sus-Anak/2014/PN.MDN.

\section{B. Metode Penelitian}

Penelitian merupakan penelitian yuridis normatif dengan pendekatan kasus, sedangkan sifat penelitian ini adalah deskriptif. Data yang dipergunakan dalam penelitian ini bersumber pada data sekunder yang terdiri atas bahan hukum primer berupa Putusan Nomor: 27/Pid.Sus-Anak/2014/PN.MDN, Undang-undang Nomor 23 Tahun 2002 tentang Perlindungan Anak, Undang-undang Nomor 11 Tahun 2012 tentang Sistem Peradilan Anak, Undang-Undang Nomor 23 Tahun 2004 tentang Penghapusan Kekerasan Dalam Rumah Tangga. Selain itu juga digunakan bahan hukum sekunder berupa karya-karya ilmiah, tulisan dan buku yang ada hubungannya dengan permasalahan yang diajukan, serta bahan hukum tersier yang diambil dari internet. Alat pengumpul data yang digunakan adalah studi dokumentasi (library research). Untuk dapat memecahkan permasalahan yang ada serta untuk dapat menarik kesimpulan dan memanfaatkan data yang telah dikumpulkan melalui studi dokumen, maka hasil penelitian ini dianalisis dengan menggunakan analisis yuridis kualitatif.

\section{Hasil Penelitian dan Analisis}

\section{Pertanggungjawaban pidana}

Pertanggungjawaban pidana disebut sebagai toerekenbaraheid, criminal responsibility, criminal liability. Pertanggungjawaban pidana dimaksudkan untuk menentukan apakah seseorang tersangka/terdakwa dipertanggungjawabankan atas suatu tindak pidana (crime) yang terjadi atau tidak (E.Y. Kanter dan S.R. Sianturi, 2012: 250). Menurut Ruslan Saleh (2011: 37), pertanggungjawaban pidana adalah suatu perbuatan yang tercela oleh masyarakat yang harus dipertanggungjawabkan pada si pembuatnya atas perbuatan yang dilakukan. Dengan mempertanggungjawabkan perbuatan yang tercela itu pada si pembuatnya, apakah si pembuatnya 
juga dicela ataukah si pembuatnya tidak dicela. Pada hal yang pertama maka si pembuatnya tentu dipidana, sedangkan dalam hal yang kedua si pembuatnya tidak dipidana.

Hanafi Amrani da Mahrus Ali (2015: 20-21), menjelaskan bahwa konsep pertanggungjawaban dalam hukum pidana merupakan konsep sentral yang dikenal dengan ajaran kesalahan. Dalam Bahasa Latin ajaran kesalahan dikenal dengan sebutan "mens rea". Doktrin mens rea dilandaskan pada suatu perbuatan tidak mengakibatkan seseorang bersalah kecuali jika pikiran orang itu jahat. Dalam Bahasa Inggris doktrin tersebut dirumuskan dengan an act does not make a person quilit, unless the mind is legally blameworthy. Berdasarkan asas tersebut, ada dua syarat yang harus dipenuhi untuk dapat memidana seseorang, yaitu ada perbuatan lahiriah yang terlarang atau perbuatan pidana (actus reus) dan ada sikap batin jahat atau tercela (mens rea). Seseorang dikatakan secara hukum bertanggungjawab untuk suatu perbuatan tertentu adalah bahwa ia dapat dikenakan suatu sanksi dalam kasus perbuatan yang berlawanan. Normalnya, dalam kasus sanksi dikenakan terhadap deliquent adalah karena perbuatannya sendiri yang membuat orang tersebut harus bertanggungjawab. Dalam kasus ini subyek responsibility dan subjek kewajiban hukum adalah sama. Menurut teori tradisional, terdapat dua macam pertanggungjawaban yang dibedakan, yaitu: pertanggungjawaban berdasarkan kesalahan (based on fault) dan pertanggungjawaban mutlak (absolut responsibility).

Jimly Asshiddiqie dan M. Ali Safa'at (2012: 56) berpendapat bahwa secara teoritik kemampuan bertanggungjawab dapat diartikan sebagai kondisi batin yang normal atau sehat dan mampunya akal seseorang dalam membedabedakan hal-hal yang baik dan yang buruk, atau dengan kata lain, mampu untuk menginsyafi sifat melawan hukumnya suatu perbuatan dan sesuai dengan keinsyafan itu mampu menentukan kehendaknya. Paling tidak ada 2 (dua) faktor untuk menentukan adanya kemampuan bertanggungjawab, yaitu: faktor akal dan faktor kehendak. Akal dapat membedakan antara perbuatan yang diperbolehkan dan yang tidak diperbolehkan, sedangkan kehendak dapat menyesuaikan tingkah lakunya dengan keinsyafan atas sesuatu yang diperbolehkan dan yang tidak 
diperbolehkan tadi. Keadaan batin yang normal atau sehat ditentukan oleh faktor akal pembuat. Akalnya dapat membeda-bedakan perbuatan yang boleh dilakukan dan yang tidak boleh dilakukan.

Lebih lanjut Jimly Asshiddiqie dan M. Ali Safa'at (2012: 30-31) berpendapat bahwa kemampuan pembuat untuk membeda-bedakan perbuatan yang boleh dan yang tidak boleh, menyebabkan yang bersangkutan dapat dipertanggungjawabkan dalam hukum pidana. Dapat dipertanggungjawabkannya, karena akalnya yang sehat dapat membimbing kehendaknya untuk menyesuaikan dengan yang ditentukan oleh hukum. Dapat dipertanggungjawabkannya pembuat dalam hal ini berarti pembuat memenuhi syarat untuk dipertanggungjawabkan. Mengingat asas "tiada pertanggungjawaban pidana tanpa kesalahan", maka pembuat dapat dipertanggungjawabkan jika mempunyai kesalahan. Keadaan batin pembuat yang normal atau akalnya dapat membeda-bedakan perbuatan yang boleh dilakukan dan yang tidak boleh dilakukan, atau mampu bertanggungjawab merupakan sesuatu yang berada di luar pengertian kesalahan. Mampu bertanggungjawab adalah syarat kesalahan, sehingga bukan merupakan bagian dari kesalahan itu sendiri. Oleh karena itu, terhadap subjek hukum manusia mampu bertanggungjawab unsur pertanggungjawaban pidana, sekaligus sebagai syarat kesalahan.

\section{Pertanggungjawaban pidana bagi anak yang melakukan kekerasan fisik} terhadap pembantu rumah tangga

Berdasarkan Putusan Pengadilan Nomor 27/Pid.Sus-Anak/2014/PN.MDN terdakwa Muhammad Tariq Anwar alias Pai terbukti secara sah dan meyakinkan bersalah melakukan tindak pidana kekerasan fisik dalam lingkup rumah tangga dan secara bersama-sama menyembunyikan mayat. Majelis hakim menjatuhkan hukuman terhadap terdakwa anak Muhammad Tariq Anwar alias Pai dengan pidana penjara selama 1 (satu) tahun dan (delapan) bulan di LPKA Medan. Hakim menetapkan masa penangkapan dan penahanan yang telah dijalani Anak Muhammad Tariq Anwar alias PAI dikurangkan seluruhnya dari pidana yang dijatuhkan. Majelis hakim menetapkan Anak Muhammad Tariq Anwar alias Pai tetap ditahan, serta menetapkan barang bukti berupa 1 (satu) unit mobil Toyota 
Kijang Innova warna Putih dengan Nomor Polisi BK 247 AI tetap terlampir dalam berkas perkara untuk dipergunakan dalam berkas atas nama H. Shamsul Rahman, selain itu, majelis hakim juga membebankan biaya perkara kepada negara sejumlah Rp. 1.000 (seribu rupiah).

Berdasarkan vonis Majelis Hakim dapat disimpulkan bahwa putusan tersebut didasarkan pada pertimbangan setiap unsur-unsur dari dakwaan jaksa penuntut umum telah terpenuhi. Dakwaan pertama, yaitu Pasal 44 ayat (1) Undang-undang Nomor 23 Tahun 2004 dengan unsur-unsur sebagai berikut:

a. Setiap orang

Pada dasarnya kata "setiap orang" menunjukkan kepada siapa orangnya yang harus bertanggungjawab atas perbuatan atau kejadian yang didakwakan itu atau setidak-tidaknya mengenai siapa orangnya yang harus dijadikan terdakwa (Lilik Mulyadi, 2012: 323). Pasal 1 butir 3 Undang-undang Nomor 31 Tahun 1999 disebutkan bahwa "setiap orang adalah orang perorangan atau termasuk korporasi".

Berdasarkan ketentuan pasal tersebut, undang-undang telah secara tegas menyebutkan bahwa pengertian setiap orang adalah orang perseorangan bahkan termasuk pula korporasi, dimana orang perseorangan tersebut adalah recht person yang merupakan subjek hukum yang mempunyai hak dan kewajiban, cakap bertindak dan tidak di bawah pengampunan, sedangkan yang dimaksud dengan korporasi adalah kumpulan orang dan/atau kekayaan baik merupakan badan hukum maupun bukan badan hukum.

Menurut Putusan Mahkamah Agung Nomor 1398 K/Pid/1994 tanggal 30 Juni 1995, kata: "barang siapa" adalah sama dengan terminologi kata "setiap orang", jadi yang dimaksud dengan "barang siapa" adalah sama dengan terminologi kata "setiap orang", sehingga yang dimaksud dengan "barang siapa" disini adalah setiap orang atau pribadi yang merupakan subyek hukum yang diduga melakukan suatu perbuatan pidana atau subyek pelaku dari pada suatu perbuatan pidana yang dapat diminta pertanggungjawaban atas segala tindakannya. 
Berdasarkan fakta yang terungkap di persidangan yaitu dari keterangan saksi-saksi yang membenarkan bahwa yang dihadapkan untuk diperiksa dan diadili di persidangan ini adalah benar terdakwa Muhammad Tariq Anwar alias Pai dan keterangan terdakwa yang menerangkan bahwa dia adalah orang atau pribadi yang beridentitas sebagaimana yang tercantum dalam surat dakwaan Jaksa Penuntut Umum.

Keterangan dari saksi Fery Syahputra, dan saksi Muhammad Bahri yang menerangkan bahwa saksi Fery Syahputra, saksi Muhammad Hanafi Bahri, Shamsul Rahman dan terdakwa yang membawa Cici ke Parit, di Jalan TMD, Perladangan Katonggal, Desa Sukanalu, Kecamatan Barusjahe, Kabupaten Karo dibenarkan oleh terdakwa sebagaimana yang telah didakwakan kepadanya melakukan tindak pidana yang dapat dipidana. Berdasarkan kesaksian tersebut bahwa benarlah "setiap orang" yang dimaksud dalam unsur ke-1 dari pasal yang termuat adalah Muhammad Tariq Anwar alias Pai, dengan demikian unsur "setiap orang" telah terpenuhi.

b. Melakukan perbuatan kekerasan fisik

Melakukan perbuatan kekerasan fisik dalam Undang-undang Nomor 23 Tahun 2004 terdapat dalam Pasal 5 huruf a yang dijelaskan oleh Pasal 6, bahwa kekerasan fisik dalam lingkup rumah tangga adalah perbuatan yang mengakibatkan rasa sakit, jatuh sakit, atau luka berat.

Berdasarkan kesaksian Endang Murdianingsih, Anis Rahayu, dan Rukmiani, terdakwa sering sekali melakukan kekerasan fisik berupa pemukulan, penamparan, penendangan, dan bentuk penganiayaan lainnya yang diperkuat dengan bukti visum et repertum para korban. Kekerasan fisik yang dilakukan terdakwa mengakibatkan luka sehingga para saksi mengaku merasa sakit akibat perbuatan anak tersebut. Oleh karena itu, unsur kekerasan fisik dalam lingkup rumah tangga berupa perbuatan yang mengakibatkan rasa sakit, jatuh sakit, atau luka berat telah terpenuhi.

c. Dalam lingkup rumah tangga sebagaimana yang dimaksud dalam Pasal 5 huruf a Undang-undang Nomor 23 Tahun 2004. Lingkup rumah tangga dalam Pasal 2 Undang-undang Nomor 23 Tahun 2004, menyebutkan bahwa: 
1) suami, istri, dan anak;

2) orang-orang yang mempunyai hubungan keluarga dengan orang sebagaimana dimaksud pada huruf a karena hubungan darah, perkawinan, persusuan, pengasuhan, dan perwalian, yang menetap dalam rumah tangga; dan/atau

3) orang yang bekerja membantu rumah tangga dan menetap dalam rumah tangga tersebut.

Berdasarkan fakta-fakta hukum diketahui bahwa H. Shamsul Rahman adalah sebagai Kepala Rumah Tangga, Suami, Bapak, sekaligus Majikan, Bibi Randika adalah sebagai istri dari H. Shamsul Rahman, Ibu dari Anak, serta Majikan, Muhammad Tariq Anwar alias Pai adalah sebagai Anak, sekaligus Anak Majikan, Saksi Endang Murdianingsih, Saksi Anis Rahayu, Saksi Rukmiani adalah sebagai orang yang membantu rumah tangga dan menetap dalam rumah tangga tersebut, keseluruhannya adalah termasuk dalam lingkup rumah tangga yang dimaksudkan Pasal 44 ayat (1) Undang-undang Nomor 23 Tahun 2004, dan oleh karena itu unsur dalam lingkup rumah tangga telah terpenuhi.

Dakwaan kedua yaitu Pasal 181 KUHP jo Pasal 55 ayat (1) KUHP jo Pasal 55 ayat (2) ke-1 KUHP jo Pasal 5 ayat (2) ke-1 Undang-undang Nomor 11 tahun 2012, dengan unsur-unsur sebagai berikut:

a. Barang siapa

Menurut Putusan Mahkamah Agung Nomor 1398 K/Pid/1994 tanggal 30 Juni 1995, kata "barang siapa" adalah sama dengan terminologi kata "setiap orang". Jadi yang dimaksud dengan "barang siapa" adalah sama dengan terminologi kata "setiap orang", sehingga yang dimaksud dengan "barang siapa" adalah setiap orang atau pribadi yang merupakan subyek hukum yang diduga melakukan suatu perbuatan pidana atau subyek pelaku dari pada suatu perbuatan pidana yang dapat diminta pertanggungjawaban atas segala tindakannya (Lilik Mulyadi, 2012: 323).

Berdasarkan fakta yang terungkap di persidangan yaitu dari keterangan saksi-saksi yang membenarkan bahwa yang di hadapkan untuk diperiksa dan 
diadili di persidangan ini adalah benar bahwa terdakwa adalah orang atau pribadi yang beridentitas sebagaimana yang tercantum dalam surat dakwaan Jaksa Penuntut Umum. Keterangan dari saksi Fery Syahputra, dan saksi Muhammad Bahri yang menerangkan bahwa saksi Fery Syahputra, Saksi Muhammad Hanafi Bahri, Shamsul Rahman dan terdakwa Anak Muhammad Tariq Anwar alias Pai yang membawa Cici ke Parit, di Jalan TMD, Perladangan Katonggal, Desa Sukanalu, Kecamatan Barusjahe, Kabupaten Karo dibenarkan oleh terdakwa Anak Muhammad Tariq Anwar alias Pai sebagaimana yang telah didakwakan kepadanya melakukan tindak pidana yang dapat dipidana. Melihat kejelasan tersebut benarlah bahwa "barang siapa" yang dimaksud dalam unsur ke-1 dari pasal yang termuat adalah Anak Muhammad Tariq Anwar alias Pai.

b. Mengubur, menyembunyikan, membawa lari atau menghilangkan mayat

Kasus menyembunyikan mayat ini diawali dengan penganiayaan yang menyebabkan kematian atas korban Hermin Rusdiati. Korban dianiaya hingga lemas. Menurut kesaksian Endang Murdianingsih, Anis Rahayu, dan Rukmiani bahwa pada saat Hermin Rusdiati alias Cici yang dikatakan pingsan dan diletakkan di bawah tangga dengan keadaan tidak berdaya, para saksi atas suruhan Bibi Randika mengganti baju dan mengurut-urut badan korban dengan minyak gosok, tetapi Cici tetap tidak sadar. Melihat hal itu, Bibi Randika menyuruh para saksi untuk naik ke atas dan mengurung mereka. Berdasarkan uraian di atas, diperkirakan Cici pada saat diletakkan di bawah tangga sudah dalam keadaan tidak bernyawa. Sehingga Fery Syahputra, Muhammad Hanafi Bahri, dan Anak membawa Cici ke Parit di Jalan TMD, Perladangan Katonggal, Desa Sukanalu, Kecamatan Barusjahe, Kabupaten Karo untuk menyembunyikan mayat Cici sehingga unsur mengubur, menyembunyikan, membawa lari atau menghilangkan mayat terpenuhi.

c. Dengan maksud menyembunyikan kematian atau kelahirannya

Kesaksian dari saksi Murdianingsih, saksi Anis Rahayu, dan saksi Rukmiani mengatakan, bahwa mereka disuruh untuk menggantikan baju, mengurut-urut badan Cici pada saat Cici pingsan di bawah tangga, tetapi Cici 
tetap tidak sadar. Melihat kejadian itu, Bibi Randika menyuruh para Saksi untuk naik ke atas dan mengurung mereka. Sikap Bibi Randika yang menyuruh para Saksi untuk naik ke atas, sedangkan para saksi pada saat itu sedang mengupayakan penyelamatan Cici jelas menunjukkan bahwa pada saat itu Saksi Muhammad Bahri, Saksi Fery Syahputra dan Anak menyadari bahwa Cici sudah meninggal pada saat di tangga, tetapi mereka tidak memberitahukan kepada saksi Endang Murdianingsih, saksi Anis Rahayu dan saksi Rukmiani dan berusaha menutupinya dengan menyuruh para saksi untuk naik ke atas, sehingga jelas bahwa unsur dengan maksud menyembunyikan kematian atau kelahirannya terpenuhi.

d. Orang yang melakukan yang menyuruh melakukan, atau turut melakukan perbuatan itu

Kasus kekerasan fisik yang melibatkan terdakwa Muhammad Tariq Anwar alias Pai dari kesaksian para Saksi yang memberikan keterangan bahwa terdakwa melakukan tindak pidana penyembunyian mayat sebagai pengendara mobil Kijang Innova BK 247 AI adalah atas suruhan Fery Syahputra dengan mengancam anak sehingga anak mengikuti dan melakukan tindak pidana tersebut.

Seperti yang dijelaskan R. Soesilo bahwa perbuatan unsur turut serta terbagi atas 4 unsur, yaitu:

1) Orang yang melakukan (pleger). Orang ini ialah seseorang yang sendirian telah berbuat mewujudkan segala unsur atau elemen dari peristiwa pidana;

2) Orang yang menyuruh melakukan (doen pleger). Disini sedikitnya ada dua orang yang menyuruh (doen pleger) dan yang disuruh (pleger), jadi bukan orang ini sendiri yang melakukan peristiwa pidana, tetapi ia menyuruh orang lain, meskipun demikian tetap ia dipandang dan dihukum sebagai orang yang melakukan;

3) Orang yang turut melakukan (medepleger) "turut melakukan" dalam arti kata "bersama-sama melakukan", setidaknya harus ada dua orang, ialah orang yang melakukan (pleger) dan orang yang turut melakukan 
(medepleger) peristiwa pidana itu. Disini diminta bahwa kedua orang itu semuanya melakukan perbuatan pelaksanaan;

4) Orang yang dengan pemberian, salah memakai kekuasaan, memakai kekerasan dan sebagainyan dengan sengaja membujuk melakukan perbuatan itu (uitlokker). Orang itu harus sengaja membujuk orang lain, sedang membujuknya harus memakai salah satu dari jalan-jalan seperti dengan pemberian, salah memakai kekuasaan dan sebagainya yang disebutkan dalam pasal itu, sehingga jelas tidak dapat memakai jalan lain.

Sebagaimana yang telah diuraikan, bahwa saksi Fery Syahputra, saksi Muhammad Hanafi Bahri, Shamsul Rahman, dan anak yang membawa mayat Cici dari bawah tangga rumah Shamsul Rahman di Jalan Angsa No 17, Kelurahan Sidodadi, Kecamatan Medan Timur, Medan dan kemudian meletak-kan mayat Cici di Jalan TMD, perladangan Katonggal, Desa Sukanalu, Kecamatan Barusjahe, Kabupaten Karo, adalah bermaksud untuk menyembunyikan kematian Cici, maka perbuatan tersebut digolongkan pada turut serta melakukan, sehingga unsur menyuruh melakukan dan turut serta melakukan terpenuhi.

Muhammad Tariq Anwar sebagai pelaku tindak pidana dalam kasus ini berusia tujuh belas tahun yang merupakan usia peralihan dari masa anak-anak ke masa dewasa. Periode ini penuh resiko karena secara kultural, seseorang akan dianggap dewasa dan secara fisik memang telah menunjukkan kedewasaan anak, tetapi kenyataanya kedewasaan seseorang tidak hanya dapat dilihat dari segi fisik saja, sehingga perlindungan bagi pra dewasa juga diperlukan agar generasi penerus bangsa tetap bermutu. Orang tua yang sehat jasmani dan rohaninya harus selalu menjaga tingkah laku fisik maupun emosional anak-anak mereka.

Kondisi lingkungan dalam keluarga merupakan faktor yang sangat berperan dalam mempengaruhi pola tingkah laku dan hal apa yang akan diperbuat anak. Orang tua yang terdiri dari ayah dan ibu merupakan hal yang mendominasi terhadap pembentukan pola tingkah laku si anak. Seharusnya orang tua mendidik anak dengan agama, moral dan etika agar anak tumbuh dan berkembang dengan pola ajaran yang baik dan bertingkah laku yang baik pula. Dalam kenyataannya, 
banyak orang tua yang tidak menyadari hal ini, banyak orang tua yang mendidik anak dengan didikan yang keras, serta mencontohkan pola perilaku yang tidak baik di depan anak, sehingga anak meniru pola tingkah laku orang tuanya tersebut. Anak yang dibesarkan dalam suasana konflik, cenderung mengalami keresahan jiwa, yang dapat mendorong anak melakukan tindakan-tindakan yang negatif yang berujung kepada tindak pidana.

Keluarga merupakan lingkungan sosial yang terdekat untuk membesarkan, mendewasakan, dan di dalamnya anak mendapat pendidikan yang pertama kali. Keluarga merupakan kelompok masyarakat kecil, tetapi merupakan lingkungan yang paling kuat dalam membesarkan anak dan terutama bagi anak yang belum sekolah. Oleh karena itu, keluarga memiliki peranan yang penting dalam perkembangan anak. Keluarga yang baik akan berpengaruh positif bagi anak, sedangkan keluarga yang tidak baik akan berpengaruh negatif pula bagi anak. Hal ini dikarenakan sejak kecil anak dibesarkan oleh keluarga dan untuk seterusnya, sebagian besar waktunya adalah di dalam keluarga maka sepantasnya jika kemungkinan timbulnya deliquency itu sebagian juga berasal dari keluarga.

Sebagaimana diketahui bahwa ayah dan ibu terdakwa Muhammad Tariq Anwar juga merupakan terdakwa dalam kasus kekerasan fisik dalam lingkup rumah tangga terhadap para pembantunya yang sama dengan si anak, dan diketahui bahwa si anak melakukan tindak pidana kekerasan dalam rumah tangga terhadap para pembantunya akibat pola didikan, serta ajaran dari ayah ibunya yang kemudian ia contohkan ataupun yang ditiru. Hal ini bersesuaian dengan teori kriminologi differential association yang dikemukakan oleh Sutherland. Sutherland dalam Indah Sri Utari (2012: 91) mengatakan bahwa semua tingkah laku jahat itu dipelajari, tidak ada yang diturunkan berdasarkan pewarisan orang tua. Tingkah laku jahat itu dipelajari dari orang-orang lain dalam suatu proses interaksi. Proses peniruan oleh anak terhadap tingkah laku orang tuanya dapat dikatakan sebagai sebuah proses interaksi dan pembelajaran tingkah laku, karena orang tua merupakan orang terdekat anak dan selalu berinteraksi dengan anak. Secara tidak langsung dalam interaksi antara terdakwa dengan orangtuanya ada kesalahan pola didikan terhadap anak yang dilakukan oleh orang tua. Meskipun si 
anak merupakan pelaku tindak pidana, tetapi si anak juga merupakan korban dari pola didikan orang tua sehingga menghantarkan anak tersangkut dalam kasus tindak pidana kekerasan.

Kekerasan dalam lingkup rumah tangga terhadap pembantu seperti kasus yang terjadi dalam keluarga Muhammad Tariq Anwar alias Pai merupakan perbuatan yang dilakukan secara berulang-ulang di dalam lingkup rumah tangga yang dilakukan oleh orang tua, sehingga menjadi pola kebiasaan yang menjadikan anak merasa perbuatan negatif (terkait norma-norma atau kemanusiaan) tersebut merupakan hal yang biasa dan bukan merupakan tindakan yang salah maupun menyimpang, sehingga pola didikan yang keras yang ditanamkan sejak kecil kepada anak akan melahirkan pola dan tindakan yang keras juga dari anak tersebut.

Putusan Pengadilan Negeri Medan dengan menjatuhkan hukuman pidana penjara terhadap anak Muhammad Tariq Anwar alias Pai selama 1 (satu) Tahun 8 (delapan) bulan seharusnya tidak diterapkan kepada terdakwa yang notabene masih dikategorikan sebagai anak. Di usia tersebut anak masih sangat labil dan mudah dipengaruhi oleh lingkungannya. Pada Pasal 16 (3) Undang-undang Nomor 23 Tahun 2002 menyebutkan bahwa penangkapan, penahanan, dan penjatuhan hukuman pidana penjara bagi anak adalah upaya terakhir (the last resort). Hal ini sejalan dengan pendapat Made Shadi Astuti dalam Sri Sutatiek (2015: 54-55), dikatakan bahwa pidana penjara menimbulkan kerugian-kerugian terhadap terpidana, yaitu ketidakmampuan narapidana untuk melanjutkan kehidupan secara produktif karena terlalu lama dalam lembaga, terpidana cenderung melakukan tindak pidana lebih lanjut setelah keluar dari penjara, terpidana jadi lebih ahli tentang kejahatan dan menjadi lebih jahat, terpidana diberi "cap jahat" oleh masyarakat yang disebut stigma, masyarakat menolak kehadiran mantan narapidana, peraturan perundang-undangan dan pembukuan tentang kelakuan narapidana memainkan peranan dalam putusan-putusan sehubungan dengan lapangan pekerjaan maupun profesi, pemberian izin, asuransi, kredit, untuk menempuh pendidikan, dan lain-lain, kombinasi dari stigma dan kehilangan kemerdekaan yang diberikan pemerintah terlihat sebagai tekanan ketat 
dan merendahkan martabat manusia. Terlepas dari pidana penjara, hakim dapat menjatuhkan hukuman berupa tindakan selain hukuman penjara terhadap anak, yaitu berupa anak dikembalikan atau anak diserahkan kepada negara.

Muhammad Tariq Anwar alias Pai yang dijatuhkan pidana penjara seharusnya dapat diserahkan kepada negara. Penjatuhan pidana diserahkannya anak kepada negara merupakan alternatif hukuman tindakan yang dapat diberikan kepada anak mengingat keluarga anak tidak dapat mendidik anak dengan lebih baik apabila anak tersebut diserahkan kepada orang tua. Hal ini dilihat dari terlibatnya keluarga si anak dalam kasus penganiayaan sekaligus tindak pidana secara bersama-sama menyembunyikan mayat seperti yang didakwakan kepada anak. Apabila anak diserahkan kepada negara, anak dapat dididik moral dan ahklak yang baik dengan dimasukkannya anak ke dalam lembaga sosial yang mampu memberikan anak modal pendidikan sebagai bekal masa depannya. Tindakan ini dilakukan dengan mempertimbangkan asas dan tujuan penyelenggaraan perlindungan anak, serta prinsip-prinsip dasar konvensi hak anak, salah satunya adalah “ demi kepentingan terbaik bagi anak". Kepentingan terbaik bagi anak adalah bahwa semua tindakan menyangkut anak yang dilakukan oleh pemerintah, masyarakat, badan legislatif dan badan yudikatif, harus menjadikan kepentingan yang terbaik bagi anak.

Penjatuhan hukuman penjara juga tidak tepat diterapkan pada terdakwa, karena pada beberapa kesaksian dan keterangan terdakwa dan uraian tentang kronologi kejadian tindak pidana tersebut anak melakukan tindak pidana dikarenakan mendapat ancaman dari saksi Fery Syahputra yang juga saksi benarkan dalam persidangan. Anak membawa mobil Kijang Innova BK 247 AI atas ancaman Fery Syahputra dengan mengatakan "kau bawa mobil kalo kau gak mau tahu sendiri akibatnya, keluargamu akan dihabisi”. Dari ancaman tersebut jelas terlihat keterpaksaan anak melakukan tindak pidana, dikarenakan tidak ada pilihan lain untuk menghindar dan cenderung mengikuti segala perintah dari orang yang mengancam. Hal ini diperkuat oleh kesaksian ahli Elmeida Effendy, bahwa anak melakukan perbuatan tersebut karena mendapat ancaman dari Fery Syahputra dan merasa terpaksa. Seharusnya pasal yang diterapkan merupakan 
Pasal 48 KUHP yang mengatur bahwa orang melakukan perbuatan karena terpaksa oleh suatu paksaan yang tidak dapat dihindarkan, tidak boleh dihukum.

Selanjutnya, jika dilihat dari proses pemeriksaan anak terdapat beberapa kejanggalan yang terjadi, misalnya saja dalam proses penyidikan anak diperiksa oleh penyidik yang bukan penyidik anak. Hal ini jelas bertentangan dengan Pasal 26 ayat (1) Undang-undang Nomor 11 tahun 2012, yang mengatur:

a. Penyidikan terhadap perkara Anak dilakukan oleh Penyidik yang ditetapkan berdasarkan Keputusan Kepala Kepolisian Negara Republik Indonesia atau pejabat lain yang ditunjuk oleh Kepala Kepolisian Negara Republik Indonesia.

b. Pemeriksaan terhadap Anak Korban atau Anak Saksi dilakukan oleh Penyidik sebagaimana dimaksud pada ayat (1).

c. Syarat untuk dapat ditetapkan sebagai Penyidik sebagaimana dimaksud pada ayat (1) meliputi:

1) telah berpengalaman sebagai penyidik;

2) mempunyai minat, perhatian, dedikasi, dan memahami masalah Anak;

3) telah mengikuti pelatihan teknis tentang peradilan Anak.

Selain itu, dalam proses pemeriksaan di kepolisian (penyidikan) anak tidak didampingi oleh penasihat hukum ataupun Balai Pemasyarakatan sehinggaAnak mendapatkan perlakuan kejam dan tidak manusiawi. Proses penyidikan ini juga dilakukan oleh penyidik vice control (VC) tidak pada unit Pelayan Perempuan dan Anak (PPA), sehingga anak juga menyaksikan pemeriksaan yang dilakukan terhadap orang dewasa. Hal ini dapat diartikan bahwa anak tidak dilindungi dari pengaruh buruk yang dapat diterimanya karena menyaksikan langsung proses pemeriksaan tindak pidana lainnya.

Berdasarkan uraian di atas, penjatuhan pidana penjara bagi anak berdasarkan Putusan Pengadilan Negeri Medan tersebut akan berdampak negatif bagi anak. Salah satu dampak negatif apabila pidana penjara bagi anak diterapkan adalah berkaitan dengan proses pembelajaran seorang anak untuk menjadi lebih jahat dari sebelumnya, karena di dalam penjara keberadaan para narapidana secara bersama-sama dan terus-menerus membentuk sebuah masyarakat yang mempunyai suatu sistem sosial khusus, sehingga dikhawatirkan terjadi proses 
penyerapan tata cara kehidupan, moral, kebiasaan dan kultur umum kehidupan di dalam penjara diserap oleh anak, walaupun penyerapan tersebut tidak selalu sempurna, tetapi dapat diasumsikan bahwa penyerapan tata cara kehidupan, moral, kebiasaan dan kultur umum oleh anak pidana mengarah pada cara-cara kehidupan yang tidak baik ke depannya untuk tumbuh kembang anak setelah anak tersebut kembali ke dalam masyarakat dan berinteraksi secara sosial. Hal ini menggambarkan bahwa penjara merupakan sekolah kejahatan atau pabrik kejahatan.

Penjatuhan pidana penjara bagi anak akan menempatkan anak untuk tinggal dan melangsungkan kehidupannya di dalam penjara. Seperti yang diketahui bahwa masih kurangnya sarana maupun fasilitas di dalam penjara atau sekarang yang lebih sering disebut lembaga pemasyarakatan sangat memprihatinkan. Seperti masalah pendidikan, kurangnya tenaga pengajar, serta keterbatasan pendidikan yang diberikan merupakan salah satu dari sekian banyak masalah mengenai pendidikan di penjara atau lembaga pemasyarakatan. Hal ini dapat dilihat dari tenaga pengajar di Lembaga Pemasyarakatan merupakan Petugas Lapas itu sendiri. Melihat hal ini sudah jelas bahwa tumbuh kembang serta pendidikan anak akan terganggu dan anak tidak bisa menjalankan kehidupan yang layak yang sebagaimana seharusnya ia peroleh. Hal ini akan sangat berpengaruh terhadap masa depan anak.

Penjatuhan pidana penjara terhadap terdakwa yang usianya masih berstatus anak juga dikhawatirkan akan menjerumuskan anak ke dalam tindak-tindak pidana lainnya. Hal ini dikarenakan terpidana anak akan bertemu dengan terpidana-terpidana anak lainnya dengan kasus-kasus kejahatan yang berbedabeda. Efek jera yang diharapkan agar anak bisa berubah menjadi lebih baik tidak akan tercapai jika lingkungan yang diberikan kepada anak merupakan lingkungan Lembaga Pemasyarakatan. Penempatan di Lembaga Pemasyarakat bagi anak juga akan berdampak negatif terhadap kondisi jiwa dan mental anak yang dapat menghambat tumbuh kembang si anak dikarenakan ia secara langsung terpisah dengan orang tuanya, saudaranya, ataupun teman-teman sebayanya. Selain itu, penempatan anak di Lembaga Pemasyarakatan akan memberikan label jahat 
kepada anak hingga ia nantinya keluar dan bergabung kembali ke dalam masyarakat.

Masyarakat akan melabelisasi anak seumur hidup menjadi mantan narapidana yang akan secara tidak langsung dijauhkan dan dikucilkan dari masyarakat. Hal ini akan sulit dalam mewujudkan cita-citanya maupun melangsungkan kehidupannya. Oleh karena itu, seharusnya anak dibina di Lembaga Sosial yang dapat secara efektif membina anak dengan mengajarkan anak kebaikan dan berbagai keterampilan terhadap anak sehingga keterampilan tersebut berguna baginya setelah ia keluar dari Lembaga Sosial tersebut dan bergabung kembali dengan masyarakat sebagaiman mestinya.

Putusan Pengadilan tingkat pertama yang menjatuhkan pidana penjara bagi anak dengan alasan agar anak tesebut jera dan tidak melakukan tindak pidana yang lainnya. Efek jera seperti yang diharapkan Putusan Pengadilan tersebut tidak beralasan dikarenakan tujuan pemidanaan dalam teori modren tidak lagi sematamata agar anak pelaku kejahatan mengalami penderitaan sehingga menjadi jera, melainkan pada pembinaan agar anak yang bersangkutan menjadi lebih baik. Prinsip penegakan hukum terhadap anak yang berkonflik dengan hukum adalah demi kepentingan anak, sehingga pidana penjara seharusnya diganti menjadi penjatuhan tindakan atau mengembalikan dan/atau menjadikan anak sebagai Anak Negara sehingga dibina menjadi manusia yang lebih baik untuk masa depannya.

\section{Simpulan dan Saran}

\section{Simpulan}

a. Pertanggungjawaban merupakan konsep sentral yang dikenal dengan ajaran kesalahan, sehingga perbuatan seseorang tidak dapat disebut bersalah kecuali jika pikiran orang itu jahat. Kemampuan bertanggungjawab dapat diartikan sebagai kondisi batin yang normal atau sehat dan mampunya akal seseorang dalam membeda-bedakan hal-hal yang baik dan yang buruk, atau dengan kata lain, mampu untuk menginsyafi sifat melawan hukum suatu perbuatan dan sesuai dengan keinsyafan itu mampu menentukan kehendaknya. 
b. Penjatuhan pidana penjara kepada Muhammad Tariq Anwar alias Pai adalah tidak tepat, karena tujuan pemidanaan dalam teori moderen tidak lagi semata-mata agar yang bersangkutan mengalami penderitaan sehingga menjadi jera, melainkan lebih kepada pembinaan agar anak yang bersangkutan menjadi lebih baik. Prinsip penegakan hukum terhadap anak yang berkonflik dengan hukum adalah demi kepentingan anak, sehingga pidana penjara seharusnya diganti menjadi penjatuhan tindakan atau mengembalikan dan/atau menjadikan anak sebagai Anak Negara.

\section{Saran}

a. Pengadilan hendaknya lebih mempertimbangkan penjatuhan hukuman penjara bagi terdakwa yang usianya masih tergolong usia anak, karena penjatuhan pidana penjara bagi anak belum tentu akan menjerakan si anak

b. Pembuat undang-undang hendaknya mempertimbangkan hukuman pidana penjara bagi anak untuk dihilangkan dan diganti dengan penjatuhan pidana tindakan ataupun pengembalian anak menjadi Anak Negara. 


\section{DAFTAR PUSTAKA}

\section{Buku:}

Gultom, Maidin. 2012. Perlindungan Hukum terhadap Anak dan Perempuan. Bandung: Refika Aditama.

Hanafi Amrani dan Mahrus Ali. 2015. Sistem Pertanggungjawaban Pidana Perkembangan dan Penerapan. Jakarta: Rajawali Pers.

Indah Sri Utari. 2012. Aliran dan Teori dalam Kriminologi. Yogyakarta: Thafa Media.

Jimly Asshiddiqie dan M. Ali Safa'at. 2012. Teori Hans Kelsen tentang Hukum. Jakarta: Konstitusi Pers.

Kanter, E.Y. dan S.R. Sianturi. 2012. Asas-asas Hukum Pidana di Indonesia dan Penerapannya. Jakarta: Storia Grafika.

Marlina. 2012. Peradilan Pidana Anak di Indonesia. Bandung: Refika Aditama.

Nasir Djamil, M. 2012. Anak Bukan untuk Dihukum. Jakarta: Sinar Grafika.

Sri Sutatiek. 2015. Hukum Pidana Anak di Indonesia. Yogyakarta: Aswaja Pressindo.

\section{Peraturan Perundang-undangan:}

Republik Indonesia, Undang-undang Nomor 1 Tahun 1974 tentang Pokok-pokok Perkawinan.

Republik Indonesia, Undang-undang Nomor 23 Tahun 2004 tentang Penghapusan Kekerasan RumahTangga.

Republik Indonesia, Undang-undang Nomor 11 Tahun 2012 tentang Sistem Peradilan Anak.

Republik Indonesia, Undang-undang Nomor 35 Tahun 2014 tentang Perubahan Atas Undang-undang Republik Indonesia Nomor 23 Tahun 2002 tentang Perlindungan Anak.

\section{Jurnal:}

Tengku Erwinsyahbana. 2012. "Perspektif Hukum Perkawinan Antar Agama yang Berkeadilan Dikaitkan dengan Politik Hukum Perkawinan Indonesia dalam Rangka Pembangunan Hukum Keluarga Nasional". Indonesian Journal of Dialectics (IJAD). Vol. 2. No. 2. Agustus. Bandung: Unpad Press. 


\section{Internet:}

Aminah Aziz. "Aspek Hukum Perlindungan Anak". http://repository.usu.ac.id/ bitstream/12345678/4/Chapter\%201.pdf. Diakses tanggal 4 Januari 2017. Pukul 18.27 WIB.

Ruslan Saleh. "Pertanggungjawaban Pidana". http://digilib.unila.ac.id/532/7/ BAB\% 20II. pdf. Diakses tanggal 23 Januari 2017 Pukul 19.58 WIB. 


\title{
BIODATA PENULIS
}

\author{
Nama $\quad$ : Atikah Rahmi, S.H., M.H \\ Pekerjaan : Dosen Fakultas Hukum Universitas Muhammadiyah Sumatera \\ Utara \\ Jabatan : Lektor \\ Nomor HP : : 082164617373 \\ E-mail $\quad$ : atikahrahmi@umsu.ac.id \\ Alamat Kantor : Jl. Kapten Muchtar Basri No. 3, Medan
}

Nama $\quad$ : Suci Putri Lubis, S.H.

Pekerjaan : Bank Mandiri Cabang Padangsidempuan

Jabatan $\quad$ : Teller Kriya

Nomor HP ： 085206453711

E-mail $\quad$ : suciputri70@gmail.com

Alamat Kantor : Jl. Sudirman No. 30-32, Padangsidimpuan 